\title{
CORPS ETRANGER DANS LES VOIES AERIENNES PAR ECLATEMENT D'UN BALLONNET DE TUBE TRACHEAL
}

\author{
Yves C. Landry et O'Donnell Bedard
}

EN VUE DE microchirurgie pour papillome de la corde vocale gauche, on intube la trachée d'un homme de 45 ans avec un tube Rüsch de calibre $4.5 \mathrm{~mm}$. Le ballonnet est gonfié avec $10 \mathrm{~cm}$ d'air environ pour assurer l'étanchéité. La ventilation est contrôlée manuellement et l'anesthésie entretenue avec oxygène et enflurane.

Au début de la microlaryngoscopie, le ballonnet du tube trachéal éclate soudainement, ce qui impose de le remplacer avant d'aller plus loin.

A l'examen du tube retiré, on remarque un trou de $1 \mathrm{~cm}$ de diamètre dans la paroi du ballonnet; à la fin de l'intervention, une bronchoscopie a permi de récupérer la partie manquante du ballonnet dans la trachée près de la carène (figure 1).

\section{Discussion}

La microchirurgie du larynx impose l'emploi de tubes trachéaux de petit calibre. Pour obtenir l'étanchéité avec le ballonnet, il faut parfois utiliser des volumes d'air assez grands et ainsi exercer une forte pression pour distendre le balIonnet; la possibilité de rupture du ballonnet est réelle et constitue un risque accepté. Cette rupture se fait généralement par simple fissure et il est rare qu'une pièce complète se détache du ballonnet. Un cas semblable a été rapporté en 1966 avec un tube qui avait été stérilisé à quelques reprises. ${ }^{1}$ Le tube trachéal que nous avions utilisé n'avait jamais servi et à notre connaissance, c'est la première fois qu'un incident semblable est rapporté avec un tube neuf. Ce genre d'incident est rare et il nous semble opportun de souligner la nécessité qu'il y a de vérifier attentivement tout ballonnet qui éclate.

La publication récente de l'essai d'un tube trachéal de petit calibre avec un ballonnet de plus grand volume pour la microlaryngoscopie nous apparaitt une alternative très valable au tube conventionnel. ${ }^{2}$ On peut espérer avec un tel tube éliminer complètement les problèmes d'éclatement de ballonnet.

Yves C. Landry, M.D., O’Donnell Bedard, M.D., Hotel-Dieu de Levis, 143 Rue Wolfe, Levis, Quebec, Canada G6V $3 Z 1$.

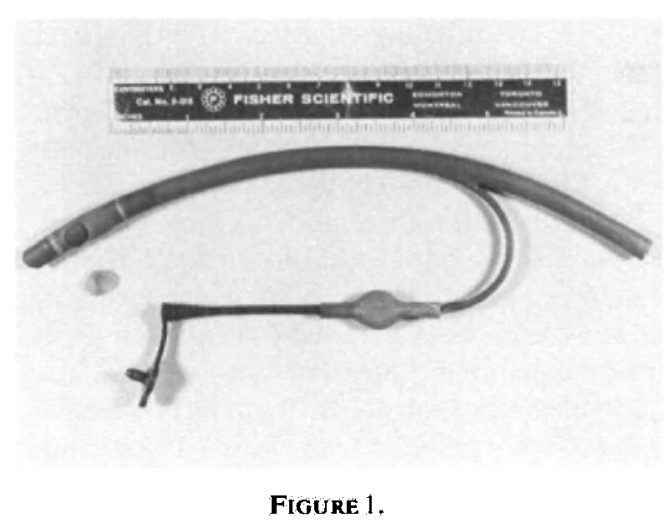

SUMMARY

Microsurgery of the larynx imposes the necessity to employ a small calibre treacheal tube. To obtain an air-tight seal with the cuff it is sometimes necessary to use large volumes of air and high pressure to distend the cuff. Rupture of the cuff is an accepted risk. Such a rupture usually results in a simple tear in the cuff.

A man 45 years of age was intubated with a new $4.5 \mathrm{~mm}$ tracheal tube for microsurgery for a papilloma of the vocal cord. The cuff ruptured and a fragment of cuff one $\mathrm{cm}$ in diameter was left as a foreign body in the airway. (Figure) This was recovered by bronchosopy. A similar occurrence has been reported with a tube which had been resterilised several times, ${ }^{1}$ but not previously when a new tube was used. A small tracheal tube with a large volume cuff which has recently been described $^{2}$ for use in microlaryngoscopy will hopefully eliminate the problems of rupture of the cuff.

\section{REFERENCES}

1. Smotrilla, M.M., Nagel, E.L. \& Frank Moya. Failure of inflatable cuff resulting in foreign body in the trachea, Anesthesiology 27:512-513 (1966).

2. Torres, G.L.E. \& Reynolds, R.C. Experiences with a new endotracheal tube for microlaryngeal surgery, Anesthesiology 52:357-359 (1980). 